\title{
Pelatihan dan Peningkatan Disiplin Kehadiran Aparat Desa Dengan Penerapan Sistem Presensi Berbasis Fingerprint
}

\author{
Randi Rizal, Aso Sudiarjo, Yusuf Sumaryana \\ Faculty of Engineering, Perjuangan Tasikmalaya University \\ randirizal@unper.ac.id
}

\begin{abstract}
Abstrak
Sesuai UU No. 6 Tahun 2014 tentang desa, proses penyelenggaraan pemerintah desa dituntut lebih optimal. Dalam hal ini, kinerja pelayanan dapat dipengaruhi oleh proses pencatatan data kehadiran aparat desa. Selama ini, pencatatan kehadiran dilakukan dengan bertanda tangan pada sebuah buku atau lembaran daftar hadir yang dilakukan saat jam masuk kerja. Dengan proses pencatatan secara manual ini, jam masuk dan pulang kerja tidak diketahui secara pasti. Selain itu, data kehadiran mudah direkayasa dengan cara menitipkan tanda tangan kepada orang lain. Berdasarkan permasalahan tersebut maka diusulkan untuk menerapkan sistem pencatatan kehadiran berbasis fingerprint. Hasil penerapan sistem kehadiran berbasis fingerprint mampu meningkatkan disiplin aparat desa dengan memberikan data otentik kehadiran yang lengkap.
\end{abstract}

Kata Kunci : Aparat Desa, Disiplin, Fingerprint, Kehadiran

\begin{abstract}
By referring to UU No. 16/2014 concerning village administering, village government is demanded to be more optimal in term of providing services. In this case, service performance can be affected by the process of recording village apparatus attendance data. So far, attendance records have been done by signing a book or attendance sheet at work hours. With this manual recording process, the exact hours of entry and return from work are not known. In addition, attendance data is easily engineered by entrusting signatures to others. Based on these problems, it is proposed to apply a fingerprint-based attendance recording system. The results of implementing a fingerprint-based attendance system were able to improve the discipline of village officials by providing complete authentic attendance data.
\end{abstract}

Keywords : Village Officials, Discipline, Fingerprint, Attendance

\section{PENDAHULUAN}

UU No. 06 Tahun 2014 tentang desa menyebutkan bahwa proses penyelenggaraan pemerintah desa perlu dioptimalkan (UU, 2014), (PP, 2015). Dalam memberikan pelayanan yang lebih maksimal kepada masyarakat maka kinerja aparat desa harus ditingkatkan. Dalam hal ini, aktifitas kerja aparat desa dipengaruhi oleh tingkat kehadiran dan kedisiplinan terhadap jadwal dan jam kerja. Selama ini, proses pencatatan dilakukan dengan pencatatan tanda tangan manual sebagai bukti kehadiran, yang memiliki banyak kekurangan seperti mudah dimanipulasi.

Beberapa metode kehadiran berbasis teknologi sudah pernah dilakukan, diantaranya penelitian (Arulogun O.T, Olatunbosun, Fakolujo O. A., \& Olaniyi, 2013), (Natalianto, Studi, Elektro, Sains, \& Dharma, 2017) dan (Saheed et al., 2016) yang menggunakan kartu Radio frequency identification (RFID) atau barcode sebagai 
identitas kehadiran. Namun masih memungkinkan terjadinya kecurangan dengan cara menitipkan kartu kepada rekan kerja. Adapula penelitian yang menggunakan aplikasi berbasis mobile android yang telah dilakukan oleh (Kendre, Markad, \& S.S.Jogdand, 2018).

Untuk mengatasi permasalahan yang ada, maka diusulkan metode pencatatan kehadiran dengan sistem biometrik. Sistem ini mengenali seseorang dengan cara mengenali pola fisik manusia, seperti: pola sidik jari (Julianto, Danuri, \& Tedyyana, 2019), pola wajah (Chau \& Banjarnahor, 2019) pola suara atau pola irismata (Singh, Singh, \& Ross, 2019). Saat ini mekanisme biometrik lazim digunakan dan paling aman, karena menggunakan otentikasi langsung pada penggunaan. Namun, yang perlu diperhatikan dari metode biometrik adalah intensitas cahaya, kualitas gambar dan distorsi dalam gambar.

Teknologi biometrik menjadi dasar dari berbagai solusi yang sangat aman untuk identifikasi dan verifikasi pribadi, serta mekanisme otentikasi yang dapat diandalkan. Otentikasi pola sidik jari merupakan salah satu implementasi dari teknologi biometrik yang memiliki lebih banyak keunggulan dibandingkan biometrik lainnya (Ezema, Eneh, \& Amanze, 2019). Selain dari itu, fingerprint juga menjadi salah satu tekologi biometrik yang paling banyak digunakan serta dengan tingkat penerimaannya baik (Fakih, Raharjana, \& Zaman, 2015). Berdasarkan latar belakang tersebut, maka kami mengusulkan penerapan sistem presensi berbasis fingerprint sebagai upaya untuk meningkatkan disiplin kehadiran aparat desa.

\section{METODE PELAKSANAAN KEGIATAN}

Pada kegiatan pengabdian ini, kami melakukan tiga tahapan kegiatan, sebagai berikut :

\section{A. Persiapan}

Pada tahap ini kami melakukan kunjungan awal ke lokasi mitra pengabdian di Desa Arjasari Kecamatan Leuwisari Kabupaten Tasikmalaya Jawa Barat. Data yang dikumpulkan berupa data kehadiran yang sedang berjalan, aturan jam kerja, dan data aparat desa. Pengumpulan informasi laporan rekapitulasi kehadiran setiap bulan. Pemetaan masalah yang dihadapi dalam ruang lingkup pengolahan data kehadiran yang sekarang berjalan.

\section{B. Pelaksanaan}

Pemasangan perangkat Fingerprint Time Attendace di lokasi mitra pengabdian. Input data aparat, pengaturan jam kerja, pengaturan jam kerja sesuai aturan jam kerja yang belaku di lokasi mitra pengabdian. Pelatihan penggunaan perangkat (pengenalan fitur aplikasi). Uji coba pembuatan laporan daftar hadir. 


\section{Penutup}

Peninjauan ulang penggunaan perangkat ke lokasi mitra pengabdian. Mengevaluasi tingkat kehadiran aparat desa di lokasi mitra pengabdian setelah digunakan perangkat fingerprint.

\section{HASIL KEGIATAN}

Hasil pengabdian masyarakat ini berupa penerapan sistem presensi berbasis sidik jari. Data yang harus dipersiapkan untuk konfigurasi awal adalah data karyawan, ketentuan jam kerja dan scan sidik jari karyawan. Sedangkan peralatan yang diperlukan untuk melakukan konfigurasi adalah perangkat komputer PC atau laptop, software fingerprint, koneksi jaringan antara alat fingerprint dengan komputer. Berikut tahapan kegiatan pengabdian :

\section{A. Pengumpulan Data}

Data yang diperoleh dari lokasi mitra adalah kondisi yang sedang berjalan pada desa mengenai mekanisme kehadiran yang masih manual, yaitu dengan cara melakukan tanda tangan pada kertas kehadiran. Data yang telah dikumpulkan berupa arsip dari lembar kertas daftar hadir yang telah diisi secara manual oleh aparat desa.

\section{B. Analisis}

Pengisian daftar hadir secara manual menimbulkan banyak kecurangan dan ketidakpastian validasi dari data kehadiran itu sendiri. Solusi penyelesaian masalah yang terjadi yaitu dengan menerapkan sistem kehadiran berbasis sidik jari maka tidak terjadi lagi kecurangan atau penitipan tanda tangan sehingga dapat meningkatkan disiplin aparat desa.

\section{Pengadaan Alat}

Pengadaan alat berbasis fingerprint MAGIC (lihat gambar 1).

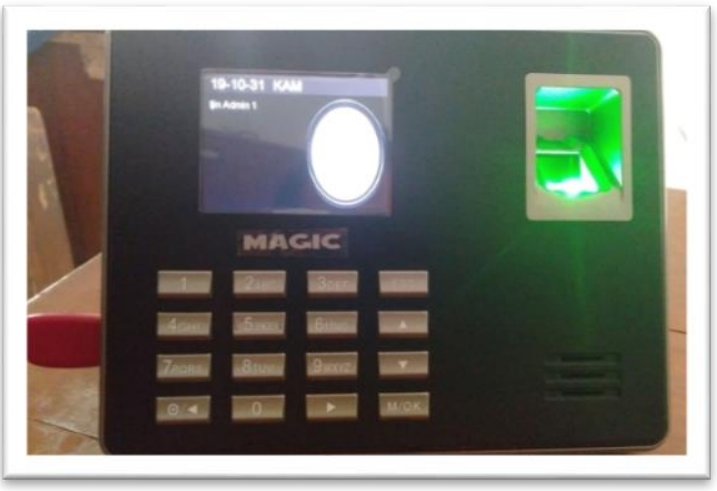

Gambar 1. Alat Kehadiran Berbasis Sidik Jari 
Sebelum melakukan pengaturan pada mesin, beberapa hal perlu diperhatikan, misalnya download setting laporan yang berfungsi untuk menyalin pengaturan. Contoh : mendaftarkan pengguna, mengatur departement, dan mengatur jadwal kerja karyawan. Langkah untuk mengunduh setting laporan adalah sebagai berikut :

1. Masukan USB Flashdisk kedalam mesin

2. Tekan menu M/OK

3. Pilih menu Laporan

4. Pilih "Unduh pengaturan lampiran laporan"

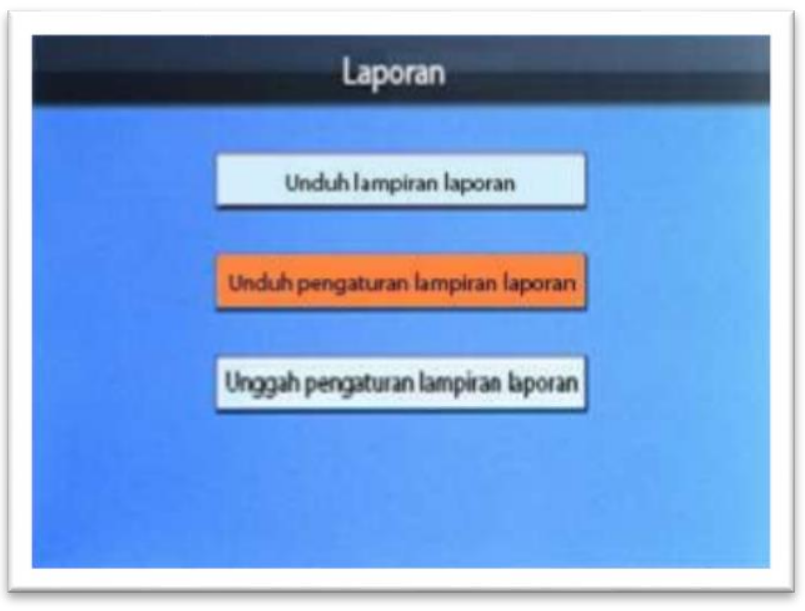

Gambar 2. Unduh Setting Mesin

5. Tunggu hingga proses download laporan selesai

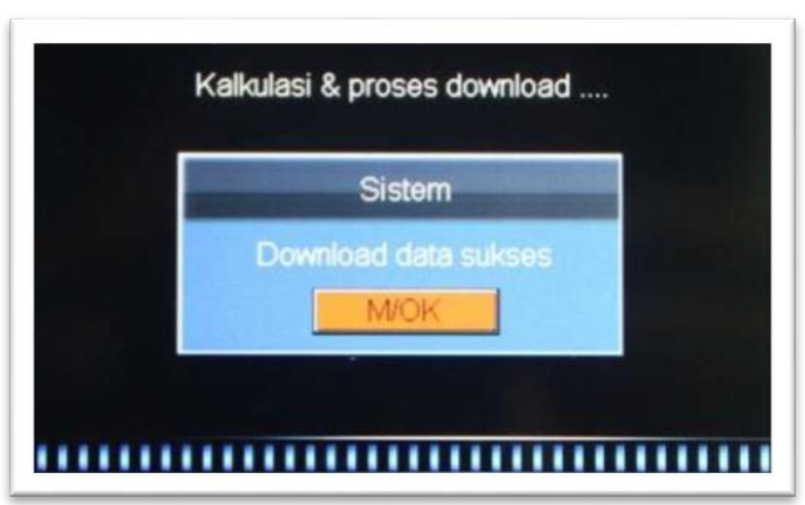

Gambar 3. Proses Download Laporan 
6. Setting pengguna dalam mesin fingerprint

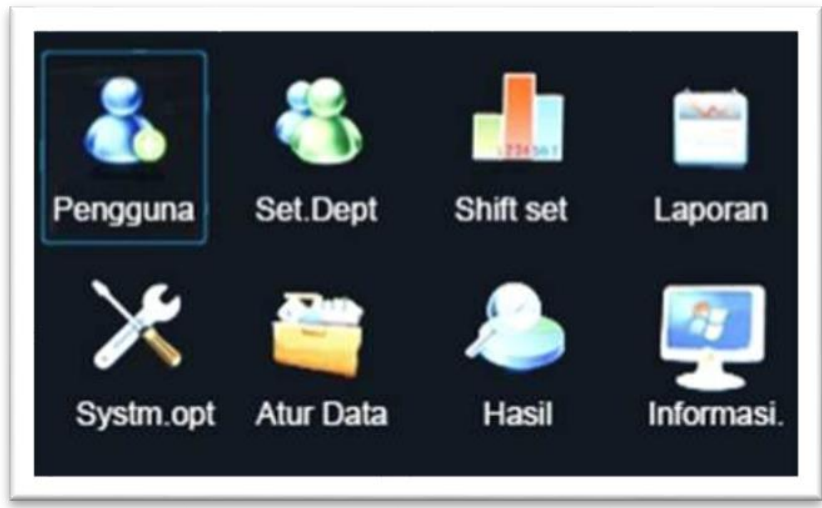

Gambar 4. Setting pengguna

\section{Konfigurasi Alat Kehadiran Berbasis Fingerprint}

Setelah alat siap digunakan, tahap selanjutnya adalah konfigurasi alat sesuai tempat mitra. Dimulai dari setting jadwal kerja aparat desa. Kegiatan pada tahap ini seperti terlihat (gambar 2).

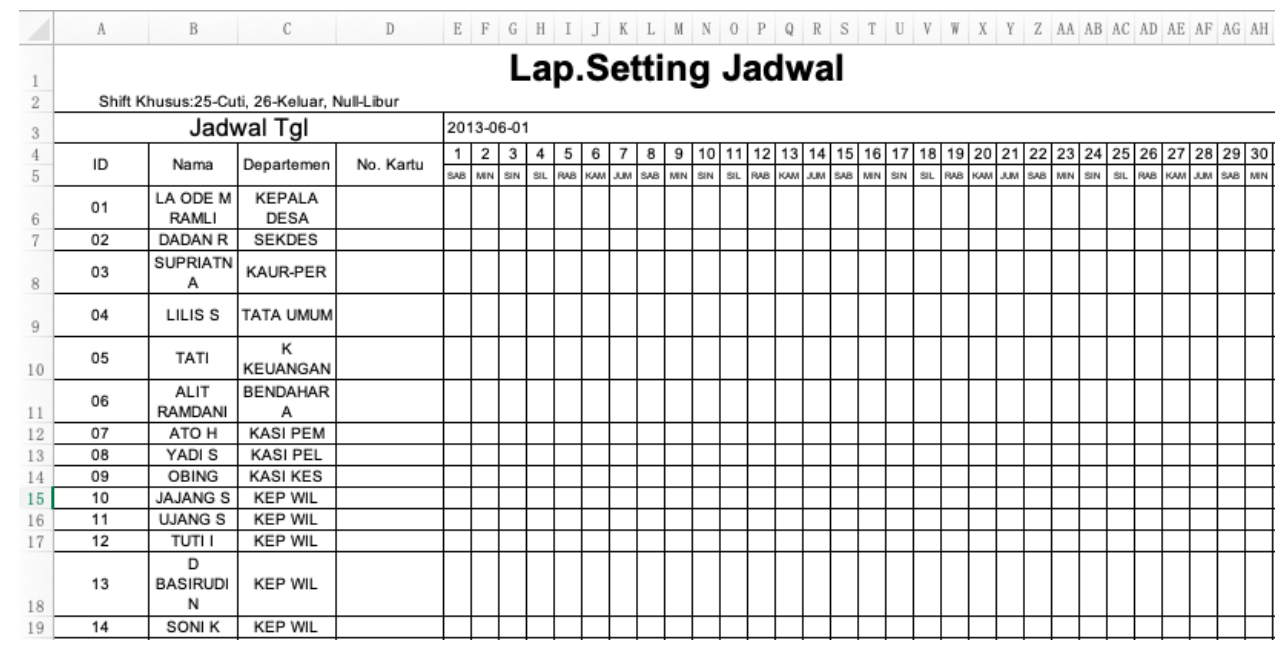

Gambar 5. Setting Jadwal Kerja Aparat Desa

\section{E. Penerapan Dan Sosialisasi Kehadiran Berbasis Fingerprint}

Sosialisasi dan pelatihan dilakukan dengan seluruh aparat desa. Setelah data aparat desa berhasil dimasukan, selanjutnya adalah melakukan scan pola sidik jari seluruh aparat desa kedalam alat kehadiran berbasis sidik jari. Nomor ID setiap aparat desa yang sudah dimasukan harus disesuaikan dengan pola sidik jari yang dimasukan kedalam alat, sehingga data pada aplikasi akan selaras dengan alat kehadiran berbasis sidik jari. Proses pengambilan pola (Gambar 5). 


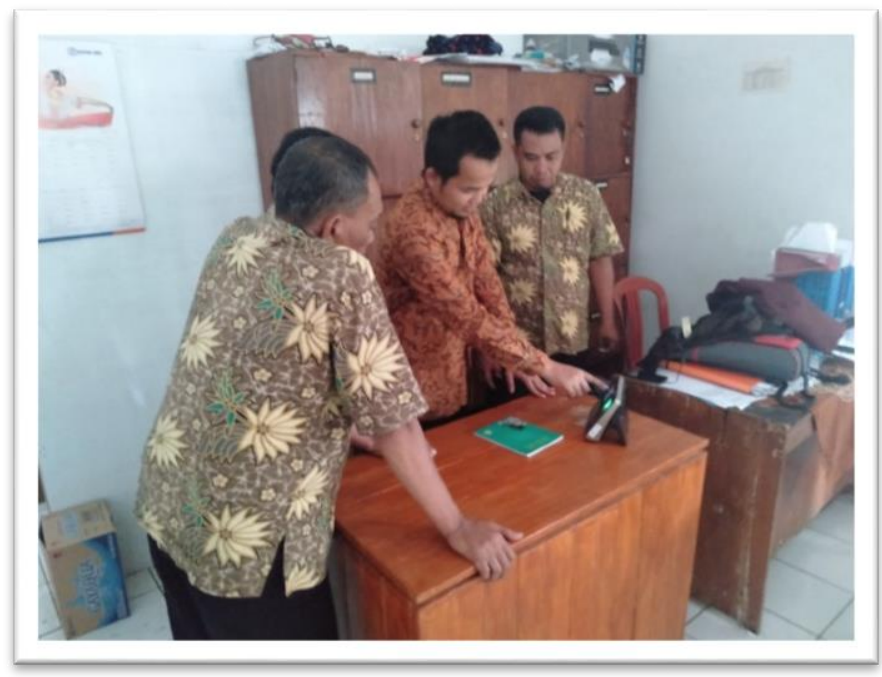

Gambar 6. Pengambilan pola sidikjari

\section{F. Uji coba pembuatan laporan}

Setelah semua aparat desa diambil pola sidik jarinya, kemudian hasil kehadiran tersebut dilihat dalam bentuk laporan. Ujicoba dilakukan download data presensi dari mesin ke komputer dan pengolahan laporan.

\begin{tabular}{|c|c|c|c|c|c|c|c|c|c|c|c|c|c|}
\hline 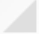 & A & B & C & D & E & $\mathrm{F}$ & G & $\mathrm{H}$ & I & $\mathrm{J}$ & K & L & M \\
\hline \multirow{3}{*}{$\begin{array}{l}1 \\
2 \\
3 \\
4\end{array}$} & \multicolumn{13}{|c|}{ Stat. $2019-10-01 \sim 2019-10-31$} \\
\hline & \multirow[t]{2}{*}{ ID } & \multirow{2}{*}{ Nama } & \multirow{2}{*}{ Departemen } & \multirow{2}{*}{ Tgl } & \multicolumn{2}{|c|}{ Timezone I } & \multicolumn{2}{|c|}{ Timezone II } & \begin{tabular}{|l|} 
Terlambat \\
\end{tabular} & Pulang & Absen & & \\
\hline & & & & & \begin{tabular}{|l|} 
Masuk \\
\end{tabular} & \begin{tabular}{|l|} 
Keluar \\
\end{tabular} & Masuk & \begin{tabular}{|l|} 
Keluar \\
\end{tabular} & (Min) & Awal (Min) & (Min) & Total (Min) & Catatan \\
\hline 5 & 01 & La Ode M Ramli & Kepala Desa & 2019-10-01 & 10.20 & 13.49 & & & 140 & 26 & 0 & 166 & \\
\hline 6 & 01 & La Ode M Ramli & Kepala Desa & $2019-10-02$ & 10.10 & 14.09 & & & 130 & 6 & 0 & 136 & \\
\hline 7 & 01 & La Ode M Ramli & Kepala Desa & $2019-10-03$ & 09.43 & 13.35 & & & 103 & 40 & 0 & 143 & \\
\hline 8 & 01 & La Ode M Ramli & Kepala Desa & $2019-10-04$ & 08.57 & 14.11 & & & 57 & 4 & 0 & 61 & \\
\hline 9 & 01 & La Ode M Ramli & Kepala Desa & $2019-10-07$ & 08.30 & 13.14 & & & 30 & 61 & 0 & 91 & \\
\hline 10 & 01 & La Ode M Ramli & Kepala Desa & $2019-10-08$ & 09.15 & 13.29 & & & 75 & 46 & 0 & 121 & \\
\hline 11 & 01 & La Ode M Ramli & Kepala Desa & 2019-10-09 & 08.57 & 14.12 & & & 57 & 3 & 0 & 60 & \\
\hline 12 & 01 & La Ode M Ramli & Kepala Desa & $2019-10-10$ & 08.05 & 13.58 & & & 5 & 17 & 0 & 22 & \\
\hline 13 & 01 & La Ode M Ramli & Kepala Desa & $2019-10-11$ & 08.02 & 14.05 & & & 2 & 10 & 0 & 12 & \\
\hline 14 & 01 & La Ode M Ramli & Kepala Desa & $2019-10-14$ & 08.05 & 13.04 & & & 5 & 71 & 0 & 76 & \\
\hline 15 & 01 & La Ode M Ramli & Kepala Desa & $2019-10-15$ & 08.09 & 13.04 & & & 9 & 71 & 0 & 80 & \\
\hline 16 & 01 & La Ode M Ramli & Kepala Desa & $2019-10-16$ & 08.21 & 13.04 & & & 21 & 71 & 0 & 92 & \\
\hline 17 & 01 & La Ode M Ramli & Kepala Desa & 2019-10-17 & 08.00 & 13.04 & & & 0 & 71 & 0 & 71 & \\
\hline 18 & 01 & La Ode M Ramli & Kepala Desa & $2019-10-18$ & 08.01 & 13.04 & & & 1 & 71 & 0 & 72 & \\
\hline 19 & 01 & La Ode M Ramli & Kepala Desa & $2019-10-21$ & 08.27 & 13.04 & & & 27 & 71 & 0 & 98 & \\
\hline 20 & 01 & La Ode M Ramli & Kepala Desa & $2019-10-22$ & 08.16 & 13.04 & & & 16 & 71 & 0 & 87 & \\
\hline 21 & 01 & La Ode M Ramli & Kepala Desa & $2019-10-23$ & 08.04 & 14.03 & & & 4 & 12 & 0 & 16 & \\
\hline 22 & 01 & La Ode M Ramli & Kepala Desa & $2019-10-24$ & 08.03 & 14.03 & & & 3 & 12 & 0 & 15 & \\
\hline 23 & 01 & La Ode M Ramli & Kepala Desa & $2019-10-25$ & 08.13 & 14.11 & & & 13 & 4 & 0 & 17 & \\
\hline 24 & 01 & La Ode M Ramli & Kepala Desa & $2019-10-28$ & 08.00 & 14.00 & & & 0 & 15 & 0 & 15 & \\
\hline 25 & 01 & La Ode M Ramli & Kepala Desa & $2019-10-29$ & 08.03 & 14.10 & & & 3 & 5 & 0 & 8 & \\
\hline 26 & 01 & La Ode M Ramli & Kepala Desa & $2019-10-30$ & 08.03 & 14.15 & & & 3 & 0 & 0 & 3 & \\
\hline 27 & 01 & La Ode M Ramli & Kepala Desa & $2019-10-31$ & 08.00 & 14.10 & & & 0 & 5 & 0 & 5 & \\
\hline
\end{tabular}

Gambar 7. Uji coba pembuatan laporan

\section{G. Monitoring Dan Evaluasi Kegiatan}

Setelah sebulan berjalan, monitoring kinerja para karyawan aparat desa. Hal tersebut dilakukan untuk memastikan sistem dapat berjalan dan ada perubahan positif di lokasi mitra. Adapun hasil laporan statistik kehadiran di lokasi mitra (Gambar 8). 


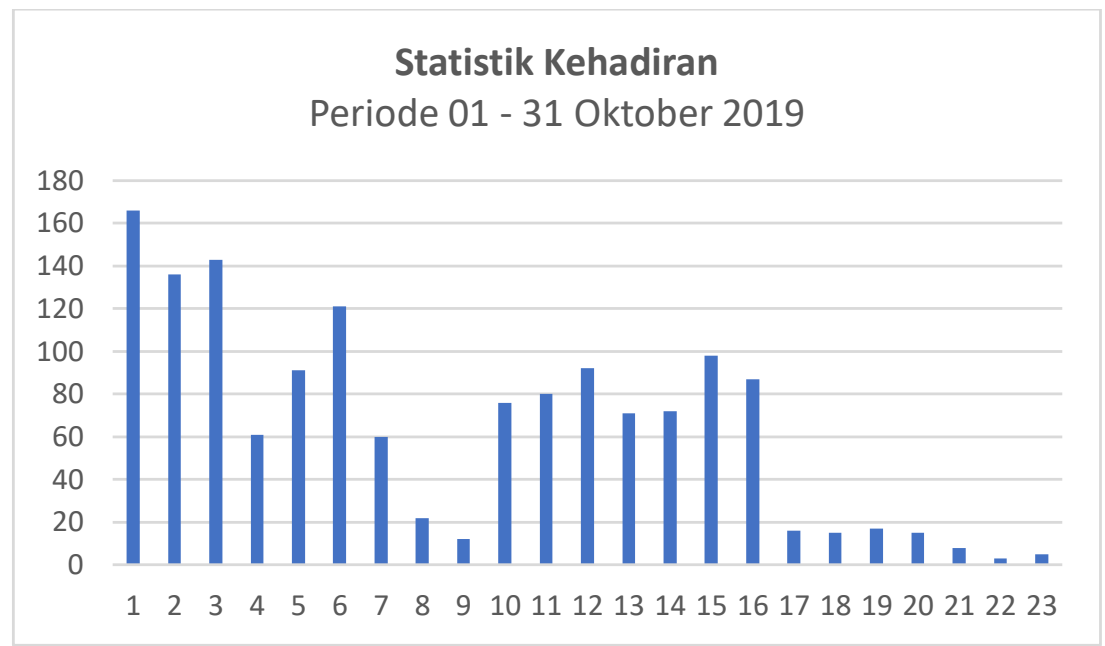

Gambar 8. Laporan Statistik Kehadiran Aparat Desa

Grafik di atas menunjukkan adanya perubahan sejak diberlakukannya presensi berbasi fingerprint. Pada minggu ke-I dapat dilihat tingkat keterlambatan paling tinggi adalah 160 menit. Sedangkan pada minggu ke IV terjadi perubahan prilaku, yaitu menurunnya jumlah aparat desa yang terlambat datang bekerja.

\section{H. Serah Terima Barang Dan Hasil Pengabdian}

Kegiatan terakhir di lokasi mitra adalah serah terima sistem kehadiran berbasis sidik jari (Gambar 9).

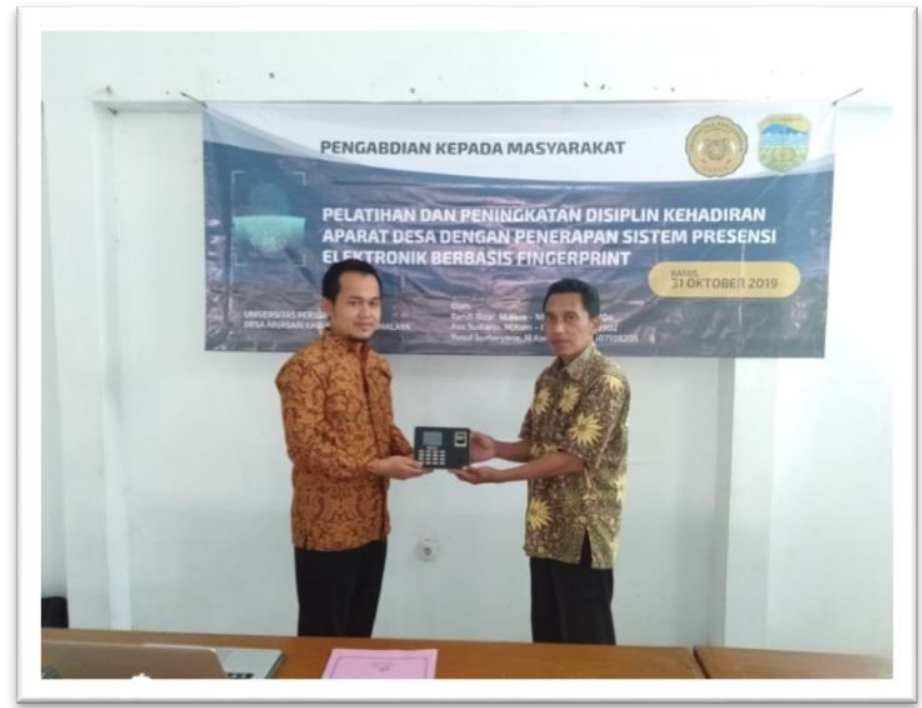

Gambar 9. Serah terima alat dan hasil pengabdian 


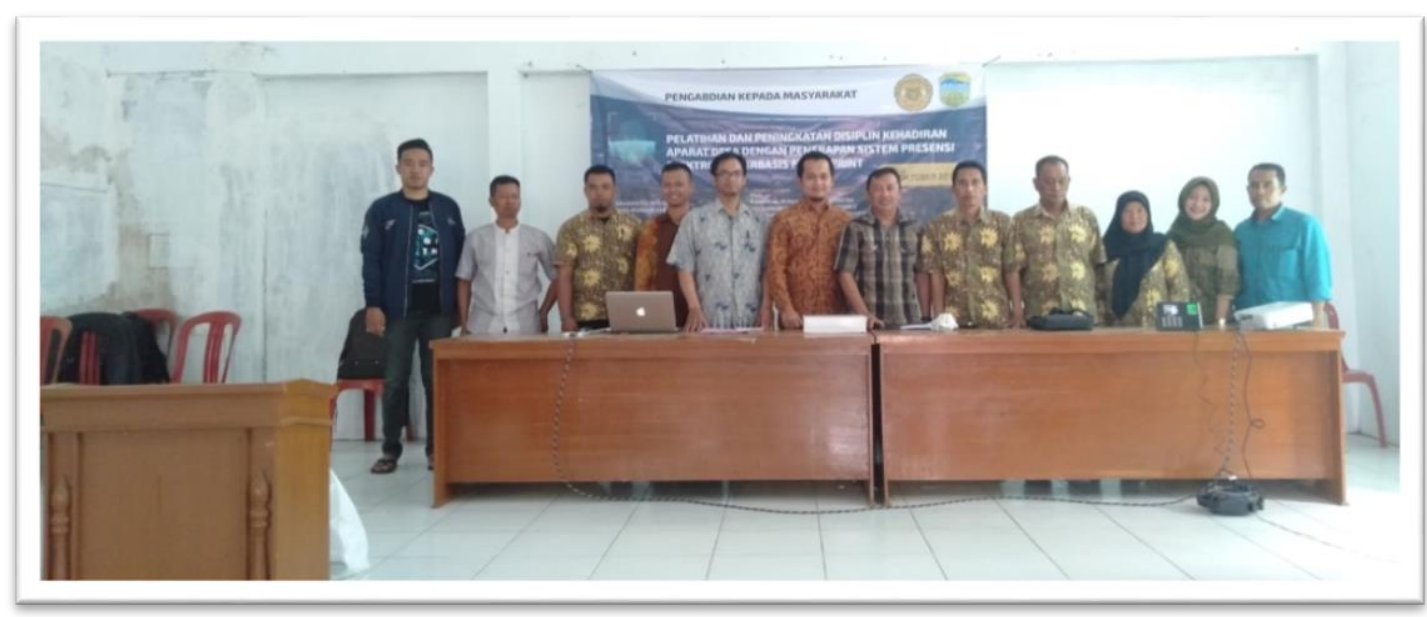

Gambar 10. Foto bersama aparat Desa Arjasari Kec. Leuwisari

\section{KESIMPULAN}

Kegiatan pengabdian masyarakat di lokasi mitra dengan menerapkan kehadiran berbasis fingerprint bisa mengatasi permasalahan yang terjadi serta dapat meningkatkan disiplin aparat desa. Laporan data kehadiran dapat dicetak langsung dan diproses secara otomatis oleh sistem. Selanjutnya, agar sistem dapat bekerja dengan lebih baik, maka diperlukan arsitektur berbasis service yang mampu menghubungkan dua platform berbeda.

\section{UCAPAN TERIMA KASIH}

Puji syukur kami panjatkan kepada Allah SWT karena atas karunia-Nya kegiatan pengabdian ini dapat terlaksana. Ucapan terima kasih yang tak terhingga juga kami sampaikan kepada:

1. LPPM Universitas Perjuangan yang telah mendukung dan memberikan dana kegiatan pengabdian masyarakat ini.

2. Pemerintah Desa Arjasari Kecamatan Leuwisari Kabupaten Tasikmalaya Jawa Barat yang telah menjadi mitra.

3. Rekan - rekan Dosen Prodi Teknik Informatika Fakultas Teknik Universitas Perjuangan

4. Pihak lainnya yang telah membantu dalam kegiatan pengabdian ini.

\section{DAFTAR PUSTAKA}

Arulogun O.T, Olatunbosun, A., Fakolujo O. A., \& Olaniyi, O. M. (2013). RFID-Based Students Attendance Management System. 4(2), 1-9.

Chau, S., \& Banjarnahor, J. (2019). Analysis of Face Pattern Detection Using the HaarLike Feature Method. Journal of Informatics and Telecommunication Engineering (JITE), 
$2(2), 62-68$.

Ezema, L. S., Eneh, J. N., \& Amanze, I. (2019). FINGERPRINT-BASED-ATTENDANCEMANAGEMENT-SYSTEM.doc. (July).

Fakih, A., Raharjana, I. K., \& Zaman, B. (2015). Pemanfaatan Teknologi Fingerprint Authentication untuk Otomatisasi Presensi Perkuliahan. Journal of Information Systems Engineering and Business Intelligence, 1(2), 41. https://doi.org/10.20473/jisebi.1.2.41-48

Julianto, A., Danuri, D., \& Tedyyana, A. (2019). Rancang Bangun Aplikasi Presensi Guru Sekolah Menggunakan Sidik Jari Dan Raspberry Pi. Digital Zone: Jurnal Teknologi Informasi Dan Komunikasi, 10(1), 54-63. https://doi.org/10.31849/digitalzone.vl0il.2176

Kendre, S., Markad, S., \& S.S.Jogdand. (2018). Android Based Attendance Management System. International Journal of Advanced Research in Computer and Communication Engineering ISO, 7(1), 190-193. https://doi.org/10.17148/IJARCCE

Natalianto, N., Studi, P., Elektro, T., Sains, F., \& Dharma, U. S. (2017). Sistem Presensi Perkuliahan Berbasis Radio Frequency Identification. Media Teknik Jurnal Teknologi, 12(2), 91-103.

PP. (2015). Peraturan Pemerintah Republik Indonesia Nomor 47 Tahun 2015 Tentang Perubahan Atas Peraturan Pemerintah Nomor 43 Tahun 2014 Tentang Peraturan Pelaksanaan Undang-Undang Nomor 6 Tahun 2014 Tentang Desa.

Saheed, Y. K., Ph, D., Hambali, M. A., Sc, M., Adedeji, A. A., Sc, B., ... Sc, M. (2016). Attendance Management System Using Barcode Identification on Students 'Identity Cards . $17(2), 224-230$.

Singh, M., Singh, R., \& Ross, A. (2019). A comprehensive overview of biometric fusion. Information Fusion, 52(i), 187-205. https://doi.org/10.1016/j.inffus.2018.12.003

UU. (2014). Undang - Undang Republik Indonesia Nomor 6 Tentang Desa. 